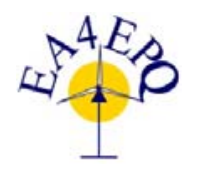

International Conference on Renewable Energies and Power Quality (ICREPQ’17)

Malaga (Spain), $4^{\text {th }}$ to $6^{\text {th }}$ April, 2017

Renewable Erengy and OPuer Quality. Sournal (RE\&PQJ)

ISSN 2172-038 X, No.15 April 2017

\title{
Why some utilities are opposed to the connection of renewable distributed sources in their distribution systems?
}

\author{
Juan Carlos Gómez Targarona, Jorge Arcurio, Jorge Vaschetti, Carlos Coyos, Carlos Ibarlucea, \\ Miguel Piumetto \\ Power Quality Research Group \\ Córdoba Regional Faculty \\ Technological National University \\ Córdoba, Argentina. \\ jcgomez_arg@yahoo.com
}

(Correspondent author)

\begin{abstract}
The today situation of the renewable distributed generation in Argentina is presented, explaining the causes of its low spread. Also the influence of the low electric energy tariffs and its non-uniformity along the country is explained. It is considered that one of the main reasons for the low application is due to the utilities opposition to this type of source, analyzing the invoked causes and the mistakes of this argument. Same international experience is also presented. Concluding in that several years will be necessary to revert this tendency and that it is very important that people takes conscience of the environment damage caused by the massive use of the fossil fuels.
\end{abstract}

Index Terms-Distributed generation, Renewable sources, Utilities, Tariffs, Distribution Systems.

\section{INTRODUCTION}

This study refers to the situation in Argentina where the connection of distributed generation is practically nonexistent.

From the year 2006 (Argentinean Laws 26,190 and 27,191 ) the use of the renewable distributed generation is under promotion, with renewable sources share requirements of $8 \%$ for ends 2017 being increased gradually until $20 \%$ for the year 2025. This scheme is applicable for customers with utility contracted power of more than 300 $\mathrm{kW}$, with financial, tributary, and other benefits, for those who incorporate this generation type [1, 2].

In spite of the two mentioned Laws, the thermal component of the energy matrix changes from $52 \%$ in the year 2006 to practically 65\% in 2015 while the renewable component does not reach $0,5 \%$. As consequence of this, the coefficient of emission of the Argentinean system of electric generation is among the highest in the planet $(0,375 \mathrm{~kg} / \mathrm{kWh})$.

For it, a Fiduciary Fund was created for the Development of Renewable Energy (FODER) to which the National Treasure should contribute not less than $50 \%$ of the saving in fossil fuels due to the incorporation of renewable sources of the previous year. The objective of the Fund is to provide funds and to grant financing, to carry out capital contributions, to grant securities, warranties, etc. For the customers whose demand is higher than $300 \mathrm{~kW}$, it exists the possibility that the demanded quantity of renewable energy can be acquired in the market. In such a case, a maximum price settles down. The nonfulfillment of such a requirement (not to reach the $8 \%$ selfgenerated or bought energy for the first year) implicate a penalty that consists on the payment of the exceeding energy to a price equivalent to the Variable Cost of Production of equivalent electric power generated from imported fuel [2]. 
There are several Law Projects for the promotion of low power renewable generation, less than 300 $\mathrm{kW}$, tending to convince the electricity customer to install a generator, becoming also an electricity producer, receiving the name of "prosumer". The scheme is based in that the customer generate the energy that he or she need, delivering the exceeding energy to the utility grid, being the utility obliged to receive this energy but technical limitations. There are nine Law Projects under analysis, coming from dissimilar Political Parties, being four of them unified in one, which have high possibility of becoming a National Law.

The analysis in the present article concentrates on renewable sources of not more than $300 \mathrm{~kW}$ for its interconnection in low and medium voltage, 220/380 V and $13.2 \mathrm{kV}$ respectively.

The law projects intend to the installation of generation equipment generating from renewable sources, without requiring of elements for the storage of the electric power, since the electric grid is used as a "cushion" that absorbs or supply the necessary energy for the balance keeping.

For political reasons, in Argentine the electric energy rates or tariffs are extremely distorted, being very low and besides the costs are widely variables through the country, for the incorporation of arbitrary subsidies. Also, the costs of the environmental damage for the use of fossil fuels and massive hydroelectric dams are not externalized, considering that the electric power has unique cost independently of the source type that generates it.

An externality, in a market scheme, is defined like a loss (or a gain) that an agent generates on a third agent without any compensation (or to be compensated) of the damage (or benefit) caused, determining a loss of efficiency in the market operation.

Then a positive externality will take place in the moment that the activity that carries out a company benefits to other activities and it is not compensated for the generation of that benefit. On the contrary, a negative externality is the one that generates a loss of efficiency as a result of a production decision or of an agent's consumption that generates a damage or additional cost at a third agent, without this last one be compensated by the agent that makes the decision.
A thermal power station produces pollution in the environment causing a damage to third agents and/or to the whole society and this company does not carry out any compensation for such a damage. Starting from that idea, applied to the concept of efficiency of the electric market, the externalization of the cost of the pollution determines a price of the energy lower than the authentic social cost of the electricity production, while the level of energy production will be superior at the socially desirable level.

In both cases, the relative price of the electricity production with polluting sources or technologies would increase with regard to other alternatives that are not contaminants, favoring this way the development and the technological substitution for companies and technologies less or non pollutants.

Although several environmentalist groups exist in Argentine, still the population in general is not much concerned neither has taken conscience of the environmental damages taken place by the massive use of fossil fuels, being one of their main use in the electric power generation. In our country 60 to $65 \%$ of the electric power is generated by thermal machines, using fossil fuel. Although it is certain that our country possesses significant fossil oil and gas resources, the fuel production is not enough being imported most of the fuel used in the country, representing a substantial strong currency leak.

Most of the components used in the generating equipment of the three more developed types of renewable energy: solar, eolic and mini-hydraulic are of foreign origin, for what its costs are considered to strong currency value (dollar or euro).

Several Argentinean provinces have aligned to the national law projects, such as Santa Fe, Mendoza, Salta, Buenos Aires, Córdoba, etc. whose renewable distributed generation enterprises are up to now fundamentally encouraged for the state, like it is the case of generation equipment installed in schools, libraries, first aids rooms, public buildings, etc. [3, 4, 5, 6].

Few provinces already have effective renewable distributed generation regulation as Santa $\mathrm{Fe}$, Mendoza, Salta, etc.

Until the moment, the scheme is active from the point of view of participation of private investors, only in Santa Fe province, by means of a simple 
and delimited in power and in enterprises number scheme. The electric energy generated by this scheme is bought by the utility at a rate of 0.32 $€ / \mathrm{kWh}$, value to be kept constant during 8 years, with a maximum power of $1.5 \mathrm{~kW}$ per prosumer, and for not more than 100 projects $[3,4]$.

The very scarce individuals' interest can be an indication that the development tools for these initiatives are yet not enough.

Figure 1 illustrates in their true dimension the potential application of photovoltaic generation in Argentine, which can be even magnified if it is compared with the potential existent in countries as Germany, Italy, etc. where solar energy is widely converted into electricity. It is expected that the main energy source to be exploited with the mentioned Argentinean legal schemes is the photovoltaic type. The few renewable cases today in operation are mostly from solar energy.

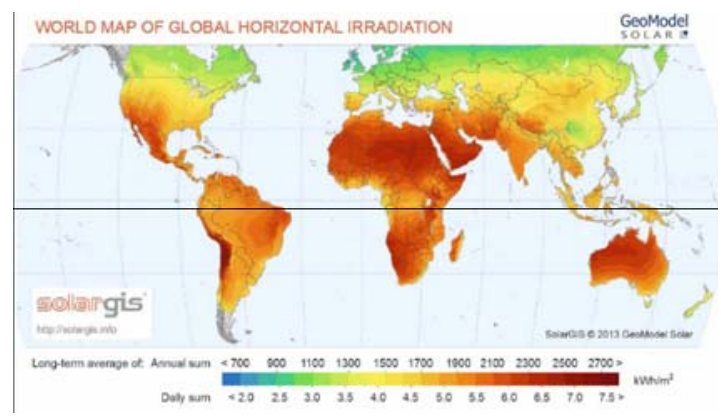

Figure 1, Map of world solar medium irradiation.

\section{CAUSES OF THE LOW SUCCESS}

The main reasons that impeded the higher development of this generation type from the point of view of the authors are:

- Low economic incentive for the investor, caused in the low electric rates or tariffs (subsidized), what is clearly shown for the bigger interest in towns or counties with higher costs of electric energy. For instance, in one of the Argentinean provinces whit higher electrical energy tariff, the cost can be divided in three items: cost of the energy purchased to the Electricity Market (approximately $0.019 € / \mathrm{kWh}$ ), Added Distribution Value (VAD, $0.065 € / \mathrm{kWh}$ ) and Value Added Taxes plus Regional Taxes (tax $0.026 € / \mathrm{kWh}$ ) resulting in a final cost of $0.11 € / \mathrm{kWh}$ [7]. The real cost of the energy at the Electricity Market should be of approximately $0.07 € / \mathrm{kWh}$ (3.7 times the paid amount).

- As the population in general is not even very well informed of the environmental damages that causes the use of fossil fuels, only a low ecological incentive exists

- It is very present the concept of inequality regarding the property of the generation equipment and their owner's benefit, being thought that the owner receives economic benefit and the society pays it to him, frequently forgetting that the benefit of improving the environment is received by the whole society. Unfortunately, this lack of environmental sensibility leads to selfishness.

This is a problem of Argentinean idiosyncrasy and of the injustices regarding the electric rates that the last years the population have been seeing. For example in a city the cost of bimonthly electric power for a typical middle class family of four members is of $2 €$, while in another city (very similar to the previous one) the same type of family pay $30 €$, due only to political reasons.

\section{OPPOSITION OF THE UTILITIES}

It can be said that one of the first standards that regulated the technical aspects of the interconnection of distributed generators, was the IEEE Standard 1547 whose original version is of the year 2003. The fact of having been one of the first to contemplate generator with rated power below 10MVA and that were applicable to synchronous, asynchronous systems or inverters, were the fundamental reasons so that the standard became a true world reference.

On the other hand, many of the utilities are strongly opposed to the installation of the renewable distributed generation interconnected to the distribution systems of which they are the concessioner, due to the following aspects:

\section{Invoked Reason}

- $\quad$ Risk for islanding operation, ignoring the existence of highly reliable and proven at world level technologies that disconnects to the source as soon as such a situation is presented. 
- $\quad$ Danger for the personnel, idea that comes from some accidents and incidents that have taken place for connection errors and fundamentally for not having respected the personnel the security rules of mandatory application.

- Risk of damages to utilities and customers equipment, what is not possible for the today existence of extremely reliable control technologies.

- Utility control loss of the distribution system, for not being the renewable generation a firm dispachtable source. A completely groundless reason since the critical penetration level for this situation could be presented when the renewable distributed generation reach levels of penetration of $20 \%$, what is very far from to happen today in our country and it is even unlikely in the next decade.

\section{Not invoked reason (but possible and informally mentioned)}

- Losses by selling less energy (but surprisingly they are not opposed to the saving and efficient use of the electric power, which have similar consequences).

- Labor Union opposition for the need of reading more than just one energy meter (more work means more salary) or some other very weak causes such as electrocution risk.

- There is not a clear understanding of the three types of rates more used at word level: Net Metering, Net Billing and FIT. For language reasons, it is easier for Argentinean to accede to the references of the country where more problems have been had. The three theoretical conceptions of exchange or energy commercialization are: Net Metering, it is a scheme based on the net measurement of energy (kWh); Net Billing, in this case the balance is made in monetary terms. The application of this scheme requires to distinguish the Generated Energy of the Consumed Energy for the user; and Feed in Tariff (FIT), this system requires of a measurement like the Net Billing. The essential difference is that the retribution perceived by the "prosumer" by the generated energy, guarantees him a return of the investment in a term, for example, between the 5 and 7 years. If the quantity of users participating of the systems of distributed generation, or the power installed in such a condition, it is an element to evaluate their success, then FIT is the most successful system.

- Fear of customer's cheating by declaring as renewable generation when it is from fossil fuel, in other words that the injected energy is not renewable.

- Uncannily technical reasons are not invoked by the impact of these Sources in the distribution system, probably due to lack of knowledge.

- All the mentioned reasons are easily solved, if the wish of solve it exist.

\section{Appreciation mistakes}

The distribution system in Argentina suffers of structural lack of investment, reason why in the seasons of maximum demand, fundamentally during the periods of high temperatures of the summer or low temperatures of the winter, frequent blackouts take place for out of service of equipment and elements of the distribution system. These blackouts happen mostly for the operation of the overcurrent protection or directly for damages of the involved equipment.

The utilities are forgetting or they do not want to recognize the advantages of the use of the distributed generation, in front of the mentioned problem, some of which are mentioned next:

- Not to recognize saving of power losses, when decreasing the length of the path traveled by the electric power.

- It would allow selling more energy at the load peak moments.

- It liberates transmission capability.

- Differ the required investments in distribution systems.

- Improves the voltage stability.

- Allows better load following.

- Improve the Power Quality.

- Increase the reliability.

The international experience in renewable distributed generation is extensive and besides 
very well-known and strict standard for them exist.

A simple numeric example for Córdoba province shows that with a tariff increment of $3 \%$ it is achieved in five years that the renewable distributed generation can reach $1.5 \%$ of the whole provincial demand, with the payment of 50 $\%$ of the investment in such a period, with a considerable saving in emitted tons of $\mathrm{CO}_{2}$.

Frequently, utilities are indirectly opposed, with the imposition of exaggerated technical demands that have as consequence the loss of profitability of the investment. The surprising fact is that in many cases, the opposition comes from state own or cooperative companies that are institutions without ends of lucre whose objective is the benefit of the community.

\section{INTERNATIONAL EXPERIENCE}

As an example, the results of the distributed generation application in two European countries is summarized below.

\section{Germany}

When one speaks of models to be followed for the implementation and the development of a State Policy, frequently it is said that the German case for the development of the Renewable Energy is one of the more paradigmatic cases. Although some aspects can in certain cases to receive smaller critics, it is widespread idea that the German case constitutes the central pattern of study in what refers to energy transformation.

Germany has the lowest world price of the solar energy and not in fact because the radiation level is high in this country (see Figure 1), it is it due to the certainty of the investment and the maturity of the market that has conferred the FIT system.

\section{Spain}

Spain implements the system FIT very little time after Germany and a short time before the United Kingdom and Italy. In principle their implementation does not present significant differences of the German case described here.

Although for moments it was part of the successful cases as the German one, for another it was a serious call of attention since for a lot of participants of the system there were changes of rules or regulations that seriously affected their credibility and until today's there are several judicial claims.

Some analysts believe that in fact the central problem was that Spain began an energy transformation process without solving some previous and of long time ago inefficiency problems. The electric system drags a strong imbalance among the revenues for the access rates and the regulated costs of the electric system, what is denominated "tariff deficit" that is increasing day by day, reaching higher and more alarming values.

\section{CONCLUSIONS}

If it is truly sought that the implementation of a system of Distributed Generation has a significant impact, the scheme should incorporate a system of "incentives" toward the "prosumer". The development that has been observed in neighboring countries, and at national level in the counties that have already introduced regulations on the subject, do not seem to be reaching developments in a such scale that indeed show a true interest for development of the Distributed Generation. In any event, it seems that such regulations respond to a question of the "duty" or snobbery more that to a true interest of development of the renewable energy.

Such incentives mainly should be centered in the economic benefits that would mean for the user, to incorporate to the electric system under the prosumer condition.

The use of the renewable distributed generation represents a step toward the environmental improvement, which lead to the benefit of the population. The utilities opposition is weakening day by day, for the lack of consistency of the invoked reasons. Besides, the economic incentives are not presently enough to induce a strong movement of investors to the renewable distributed generation application. It is expected that in the near future the tariffs become more realistic which will impulse the renewable distributed generation interconnection.

\section{REFERENCES}

[1] Ley 26190, "Régimen de Fomento Nacional para el uso de Fuentes Renovables de Energía Destinada a la Producción de Energía Eléctrica”, December 2016. 
[2] Ley 27191, Modificaciones a la Ley 26.190, "Régimen de Fomento Nacional para el Uso de Fuentes Renovables de Energía Destinada a la Producción de Energía Eléctrica”, October 2015.

[3] Ley Provincial Santa Fe N 12.503 “Declárase de interés provincial la generación y el uso de energías alternativas o blandas (las que se producen naturalmente, en forma inagotable $\mathrm{y}$ sin ocasionar perjuicio al equilibrio ambiental)", September 2005.

[4] Ley Provincial Santa Fe N 12.692 "Régimen Promocional Provincial para la investigación, desarrollo, generación, producción y uso de productos relacionados con las energías renovables no convencionales”, December 2006.
[5] Ley Provincial Salta N 7824 "Balance Neto. Generadores Residenciales, Industriales y/o Productivos”, June 2014.

[6] Ley Provincial Mendoza N 7549 "Declaración Interés Provincial Actividades Generación Transporte Distribución Uso Consumo Energias Eólica Solar Investigación Desarrollo Transferencia Tecnología Fomento Industrias”, June 2006.

[7] Proyecto de Ley 20255E16 Provincia de Córdoba “Declara de Interés Provincial la Generación Distribuida de Energía Eléctrica a partir de Fuentes Renovables con destino a Consumo Propio de los Usuarios que la Generen, con la Posibilidad de que los Excedentes sean Inyectados a Sistema de Distribución”, October 2016. 